\title{
Trials and Errors: The Experience of Central American Refugees in Montreal
}

\author{
By Charles D. Smith
}

This article is based on the findings of a 1983-84 study of 40 Salvadorean and 35 Guatemalan exiles presently residing in Montreal. Besides culture shock and the cold, the biggest immediate problem faced by informants was coping with a plunge in economic status and living in a situation of poverty (by Canadian standards). Central Americans were happy to have escaped repression at home, but, once here, it was extremely difficult for most of them to find work. Those who did enter the labour force did mostly menial jobs, working as housekeepers, babysitters, cleaners, labourers or restaurant and factory workers. Since the majority of those interviewed came from the small, middle class portion of the Central American population, their lives here began at a much lower standard of living than they had enjoyed at home, at least before war and repression eroded their position.

\section{A Few Facts and Figures}

Quebec's Ministry of Cultural Communities and Immigration lists 3,670 arrivals to Quebec from El Salvador and Guatemala who were granted official landed immigrant status from 1980 through 1985. The largest single category was accepted as Convention refugees, but these are not a numerical majority. Convention refugees are those who meet the terms of the Geneva Convention -- are outside their country of origin and can demonstrate a well-founded fear of persecution.

When speaking of Convention refugees it is necessary to distinguish whether they are 1) claimants, 2) former claimants granted "refugee" status, or 3) Convention refugees actually accepted as landed immigrants. Only the last category are allowed full legal rights in Canada.

Refugee status determination is a lengthy process, taking as long as 3 years and very rarely less than 1 year. Some 4,000 claimants are accepted as Convention refugees each year.

The complexity of this system can be illustrated by considering the data for 1983 as an example. In that year, a total of 88,846 landed immigrants were accepted in
Canada. In the same year, 4,059 Convention refugees were granted landed immigrant status (CEIC 1983 Quarterly Statistics). That year, 2,677 refugee claims were adjudicated. Of these, $62 \%$ did not qualify. Therefore, 1,017 persons were granted refugee status (Ottawa Citizen, June $15,1985)$. Some of those selected as refugees would be granted landed immigrant status the same year, but most would have to wait another year or more to be accepted as landed immigrants. To confuse matters even more, there are about 20,000 refugee claimants in Canada who make up the backlog of those waiting for a decision on whether their claims for Convention refugee status will be accepted (Le Devoir, February 17, 1986).

The largest number of Convention refugees (among the 4,000) given landed immigrant status were the 745 Salvadoreans accepted throughout Canada. Of these, 676 chose Montreal as their "intended" new home.

For Montreal, incoming Convention refugees represented the following percentages of landed immigrants from Guatemala and El Salvador.

\section{Convention Refugees in Montreal}

GUATEMALA

\begin{tabular}{ccc} 
Year & Convention \% & $\begin{array}{c}\text { Number of Total } \\
\text { Landed Imm. }\end{array}$ \\
& & \\
1980 & .0 & 40 \\
1981 & .0 & 36 \\
1982 & 4.8 & 21 \\
1983 & 28.8 & 66 \\
& \multicolumn{2}{c}{ El SALVADOR }
\end{tabular}

$\begin{array}{ccc}\text { Year } & \text { Convention \% } & \begin{array}{c}\text { Number of Total } \\ \text { Landed Imm. }\end{array} \\ 1980 & 23 & 62 \\ 1981 & 25 & 128 \\ 1982 & 35.7 & 333 \\ 1983 & 33.8 & 678\end{array}$

In Canada as a whole, in the 1980 s approximately four in five refugee claimants were refused. Yet it seems that in some instances, the validity of the rejected claims appears to have been as great as of those accepted.

This is illustrated in the case of Roberto (not his real name), a member of a popular political opposition group in El Salvador. He reports:

I was with a group of fellow university students. We had just finished taking part in a discussion of university politics. We were standing by the bus stop when a white truck parked in front of us stopped [sic] and we heard them say, "you and you", pointing to us, "get in". We started to run away, and they opened fire. One guy was shot in the leg; another was killed by a shot in the head. One girl was taken into the truck and was killed a few blocks away ... We went back (a few hours later) and found her body lying in the street ... I could give many more examples ... At the present moment, almost all the members of my family have been rejected (as Convention refugee claimants in Canada) ... even my brother who has more than 14 stitches from an operation after being hit with the butt of a rifle, has not been believed. He has had no answer yet. It's been three years now.

His story may not be typical, but neither is it exaggerated or uncommon. The legalistic interpretation. of Convention status, as well as the uncertainty of a Convention refugee being accepted as a landed immigrant, is an area in which concerned Canadians should voice their opinions.

\section{Immigration Trends}

Certain clear trends emerge from immigration statistics. Between 1970 and 1980 Quebec accepted small and approximately equal numbers of Guatemalan (507) and Salvadorean (660) landed immigrants. But since 1979 much larger numbers have arrived, primarily Salvadoreans. In the years 1981-83 inclusive, Quebec accepted 1,773 Salvadoreans and 212 Guatemalans -- more than seven times as many Salvadoreans. This is mainly because of the special programme (to relax selection criteria for Salvadoreans) in effect between March 1981 and May 1982. Since it often takes as long as three years to process immigration dossiers, many who entered at that time only now are being finally accepted. 
The largest single group of Salvadoreans entering Canada, about one-third, chose Montreal as their home. Our research indicates that this is because of better governmental assistance in Quebec than in other provinces, prior residence of family members, and well-established Salvadorean political and community groups. For the Montreal group, during the peak immigration years, single people were the largest category; only some $30 \%$ were married. While $70 \%$ were single, less than $10 \%$ of those were separated, divorced or widowed. The sex ratios for Guatemalans and Salvadoreans were close to equal with a slight overrepresentation of males. The largest single age category of these landed immigrants was the prime working age group of 20 to 40 years old; $44.4 \%$ of Montreal's Guatemalans and $50.5 \%$ of the Salvadoreans fit into this age bracket.

\section{A Study of Refugee Adaptation}

Salvadorean immigration to Canada in the 1980 s is a good example of a migrating social group which, to a large degree, resembles the ideal type of refugee. A total of 3,587 Salvadoreans entered Canada as landed immigrants in 1983. Of these, 1,842 were not officially accepted as refugees. Yet most of them left due to the chaos, violence and insecurity of war. The vast majority of these migrants were from the middle classes. Canada Employment and Immigration data do not include previous occupation, but questionnaires administered by this author to 40 Salvadoreans and 35 Guatemalans revealed that $37.5 \%$ of the Salvadoreans and $45.7 \%$ of the Guatemalans had job experience in the white collar category. Of these, $30 \%$ of the Salvadoreans and $37.1 \%$ of the Guatemalans had been managers, professionals or scientific technicians, while the remainder were secretaries, bank tellers, sales ladies, receptionists, etc.

Forty-one percent of the Guatemalan cohor and $32 \%$ of the Salvadoreans in Montreal had been students. It is possible that many of these young people could, in time, resume their former training and gain access to the labour market in various specialized occupations in demand in Canada.

In the short and medium-term, refugees experience a drastic decline in socioeconomic status. It could be argued that perhaps they come here with unrealistic expectations of an improvement in status, and that these are not realized. Yet special
CEIC data made available to us indicated that only $11 \%$ of the Salvadorean landed limmigrants in Montreal between 1980 and 1983 intended to work as professionals, managers or entrepreneurs. As noted, 30\% of our sample population previously had been employed in these high-status categories. None of our sample actually was employed in Canada as a manager or professional. This indicates that most Salvadoreans -- especially those who may have waited three years for landed immigrant status -- have reasonably clear expectations of their prospects here.

In Central America, fewer than $1 \%$ of the total population attends university. Within our sample, $37.3 \%$ had attended university. Our study examined the family backgrounds of the respondents and we found that the overwhelming majority of the sample came from the small middle class fraction of the Central American population. On average, our respondents had either both parents working in the industrial sector or at least one working as a manager or professional. This index of class also considered the size of the family and whether or not parents were permanently together. Guatemalans scored slightly higher on this index. Both groups were predominantly Catholic (though not necessarily practising) and predominantly from urban areas.

Using discriminant analysis, we discovered that for our national samples (separate and pooled, except where otherwise indicated), seven important variables differentiated refugees from other exiles. (Refugees are defined as those who reported being members of families who were directly persecuted.) It was found that: 1) refugees were less attached to their own ethnic group; 2) refugees reported greater feelings of guilt over leaving their country and families behind; 3) refugees have to wait longer to receive their Certificat du Selection du Québec (this is corroborated by a correlation between persecution and immigration difficulty); 4) refugees were less likely to have received family assistance in immigrating to Canada; 5) the class and socio-economic status of refugees was slightly lower than that for other exiles; 6) the level of social and cultura adaptation, including proficiency in French and English, was higher for the refugee group; 7) the level of material adaptation based on disposable income, was slightly higher overall for the refugee group, although for the Guatemalan sub-sample the reverse was true.
Other marked differences between the two groups were the time it took to plan their exit from the country (refugees took an average of two months and other exiles an average of six) and the length of time spent on the journey to Canada (the average for refugees was 11 months and for exiles about eight).

Our study results indicate that the refugee group seems more independent than the other exile group. Despite disadvantages, they seem highly motivated to improve their situation and overcome feelings of guilt. This should positively affect their ability to adapt culturally and socially as well as in the job market. It also seems true that refugees are vulnerable to exploitation as cheap labour because of their semi-legal status and fear of being sent back. This was the experience reported by many of our respondents.

\section{Differentiation by Gender and Nationality}

Discriminant analysis revealed some significant differences within the Central American group. In considering gender, it was clearly established that males experienced greater migration and immigration difficulties than females and came from a higher socio-economic background than females. Women felt a stronger sense of attachment to their own ethnic group. Salvadoreans experienced significantly more problems of migration and the Guatemalans tended to adapt better on a material level. The reason for this is probably the more stringent employability criteria that have been applied thus far to a smaller, more select group of incoming Guatemalans.

\section{Persecution and Immigration}

One disturbing trend uncovered in the study was the clear association between persecution at home and migration and immigration difficulties. Within our sample, $44 \%$ of our respondents or members of their immediate families had been threatened by persecutors such as paramilitary death squads or the army. Of this high persecution group, $57 \%$ travelled to Quebec overland at least part of the way. Males generally preceded their spouses on the journey. Forty-five and one-half percent took over one month to complete the trip from their home country to Montreal. 
Once here, the high persecution group tended to have more immigration delays and problems. Of the $28.6 \%$ of Guatemalans and $37.4 \%$ of Salvadoreans in our sample who experienced immigration difficulties -- negative or late decisions, appeals -- $70 \%$ of the Guatemalans and $73.3 \%$ of the Salvadoreans were in the high persecution category. Four out of our 75 respondents were placed in preventive detention upon arrival

\section{Conclusion}

The trials faced by Central American exiles entering Canada are considerable. But for many more of their countrymen the situation is even more grave. There are approximately two million Central American refugees. Between 1979 and 1983 more than 50,000 Guatemalans and 250,000 Salvadoreans fled their countries' U.S.-backed military regimes. According to Arthur Helton, Director of the political asylum project of the Lawyers Committee for International Human Rights, a further one million left their troubled countries in 1984 (Macleans, May 13, 1985). It is believed that one million Central Americans have entered the United States where most reside illegally trying to elude the immigration authorities.

The Reagan administration insists that most of the illegal immigrants from Central America are economic migrants seeking to escape poverty rather than political represssion. The study of refugees in Montreal clearly demonstrates exactly the opposite.

The United States deported Salvadoreans and Guatemalans at the rate of 400 each month in 1984. Many would then face imprisonment or even death. The United States Immigration and Naturalization Service (INS) granted asylum to only 328 of 13,373 (3\%) Salvadorean applicants in 1984.

We, as concerned Canadians, must apply pressure on our government to continue to avoid the double error made by the United States. We must not assume Central Americans are economic migrants. My data indicates a downward plunge in economic status. But the overriding issue is that Canada, unlike the United States, must honour its humanitarian obligations as signatory to the United Nations Convention and Protocol on refugees.

The words of two American Rabbis speaking at a Tucson symposium should be taken to heart. Rabbi Marshall Meyer, who spent 25 years in Argentina, stated:

... what is happening to the Central American refugees parallels the beginnings of Nazism in Europe.

Rabbi Joseph Weiznbaum, whose father was an undocumented alien, adds:

These refugees are the Jews of today ... The good Lord has dealt out a new deck of cards, and we are the ones who must not be turning them away now.

\section{[from Reform Judaism, Fall 1985]}

Charles D. Smith is a post-doctoral fellow of the Centre for Developing Area Studies and a research project co-ordinator at McGill University's Anthropology of Development Project. This article is based on the findings of a 1983-84 study entitled "Les Réfugiés au Québec", funded by the Conseil Québecois de la recherche sociale (CQRS).

\section{New Publications}

- Memorandum Presented to the Government of Guatemala Following a Mission to the Country in April 1985 (Ottawa: Amnesty International, 1986).

- Nicaragua: The Human Rights Record (Ottawa: Amnesty International, 1986).

- Guatemala: The Group for Mutual Support 1984-1985 (New York: Americas Watch, 1985).

- The Continuing Terror: Seventh Supplement to the Report on Human Rights in El Salvador (New York: Americas Watch, 1985).

- Human Rights in Honduras After General Alvarez (New York: Americas Watch, 1986)

- Human Rights in Nicaragua: Reagan, Rhetoric and Reality (New York: Americas Watch, 1985).

- Stephen Golub, Looking for Phantoms: Flaws in the Khmer Rouge Screening Process (Washington, D.C.: United States Committee for Refugees, 1986).

- Philippa Valder, Refugees: A Dilemma for the World (Richmond, Australia: CHOMI, 1985).

- Ken Wilson, Rachel Ayling, Alexander de Waal, JoAnn McGregor, Mary Myers, Alula Pankhurst, Jonathan Wright, The Lutaya Expedition: A Report on Research in Yei River District, South Sudan (Oxford: Refugee Studies Programme, Occasional Paper Number 1, 1985).

\section{Book Reviews}

\author{
Barbara E. Harrell-Bond \\ Imposing Aid: Emergency \\ Assistance to Refugees
}

Foreword by Robert Chambers Toronto: Oxford University Press, 1986

\section{by Dawn MacDonald}

In the late 1970s, with the name Idi Amin the current synonym for madman-devil incarnate, the world's compassionate cheered the seven-month effort of Tanzanian troops to reach Kampala and topple the despot. And that, for most of us, was the end of that. If we thought about Uganda at all in the next few years, it was with complacency. Of course there would be a time of further displacement for innocent civilians but it would settle down. The international humanitarian agencies we had assigned to do our caring for us would clean up while we grappled with the news of horrors elsewhere in the world.

How wrong we were. In southern Sudan alone, the refugee count of 2,000 Ugandans at the time of Amin's exit from power grew to 300,000 in the next four years. Even more startling, only twenty percent of these numbers obtained -- correction: sought and obtained -- assistance from the UNHCR, the central agency co-ordinating the security and material needs of those in flight.

These and thousands of equally arresting facts have been presented in Dr. Barbara Harrell-Bond's new book Imposing Aid: Emergency Assistance to Refugees. But Dr. Harrell-Bond is concerned with a great deal more than the facts of this particular situation. From the outset her case study approach - two years of observing and writing about the reality of the Ugandan refugees in the Yei River district of southern Sudan -- was planned to test all the assumptions underlying the behaviour and attitudes of those who interact with African refugees (there are currently five million fleeing terror, civil war and drought and the numbers have been predicted to go as high as fifty million by the year 2004). The intervenors include UNHCR policy makers and practitioners, the voluntary nongovernmental organizations (NGOs) hired to implement UNHCR programmes, journalists, visiting delegates from donor governments, and hosts, both governmental and local, who are called upon to share their skimpy resources with the refugees. 